WORLD ANTHROPOLOGIES

\title{
Commentary
}

Why Don't Linguists Talk about Politics? Moving Forward on Language Endangerment-Together

\section{Ruth Singer}

University of Melbourne, Australia

Davis and Roche highlight the issues that arise when we try to discuss endangered languages without paying due attention to their historical, social, and political context. Davis gives an example of how linguists' overly narrow focus on language can lead to errors in counting the number of speakers of endangered languages. She discusses the Native American language Chickasaw, her own language, currently spoken mainly in Oklahoma, and shows how counts of the numbers of speakers of endangered languages can go wrong because of the assumption that the only people who speak Chickasaw are those who identify as Chickasaw. Davis reminds us that many people (both Chickasaw and non-Chickasaw) spoke Chickasaw as a lingua franca in the multilingual southeastern United States of precolonial times. She then takes us through to the current day via an account of the forced relocation of Chickasaw speakers to Oklahoma so we can understand more about the diverse group of people who contribute to the current Chickasaw-language renaissance.

Linguists' estimations of global language endangerment seem to invoke fictional Indigenous communities that are linguistically and ethnically "pure" (Shotwell 2016) even though at some other level we know well that Indigenous communities are just as multilingual and culturally diverse as any other communities (Singer and Vaughan 2018). Davis shows that we can construct a much more accurate picture of language endangerment by paying attention to the histories of Indigenous communities and life in contemporary Indigenous communities.

Roche writes in his contribution that linguists who write about language endangerment fail to "see politics." Regardless of what they are aware of, linguists writing about language

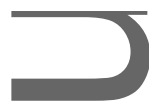

This is the and mascript accepted for publication and has undergone full peer review but has not been the th copyediting, typesetting, pagination and proofreading process, which may lead to differences betw this version and the Version of Record. Please cite this article as doi: 10.1111/aman.13375.

This article is protected by copyright. All rights reserved. 
endangerment tend to focus too narrowly on language. For the field to move forward, linguists must, as Roche points out, contextualize language endangerment as part of broader social change. However, understanding the social changes that Indigenous communities are undergoing requires linguists to build connections with other disciplines that have developed scholarly approaches to Indigenous history and contemporary Indigenous politics, society, and identity. Engaging in greater dialogue with Indigenous scholars will also help as Indigenous scholars often resist arbitrary separations created by disciplines, like the separation of language from other aspects of Indigenous lives. In her book on the Chickasaw-language renaissance, Davis (2018) contextualizes language endangerment in the lives of people who have close connections to the Chickasaw language.

A narrow definition of what constitutes language endangerment tends to marginalize the perspectives of Indigenous linguists and community members and also the perspectives of nonIndigenous linguists whose primary commitment is to Indigenous communities rather than universities. In Australia, the distance between university-based linguists and community-based linguists is growing. For example, a recent discussion on Facebook centered on a linguist's request to access archival collections of a large number of Indigenous Australian languages in order to do comparative work on Australian languages. The community-based linguists who commented agreed that it was best to turn down these kinds of requests, as it is unethical to research Indigenous Australian languages without building a relationship with the relevant Indigenous communities first, which is not possible in such large-scale comparative studies. Understanding the genuine commitment that these linguists have to the communities they work with, I was a little shocked to think that the kind of comparative work I have done in the past might no longer be considered ethical.

Many university-based linguists feel a growing tension between their obligations to the academy and to Indigenous communities, but discussions of these tensions tend to be limited to private conversations and semiprivate settings, such as Facebook. It's no coincidence that this commentary is appearing in an anthropology journal rather than a linguistics journal. Linguists struggle to discuss these tensions in public, although such conversations are commonplace among those who research Indigenous topics in other humanities disciplines. Is this because we lack the training to articulate ideas about anything but language in a scholarly way, or are we concerned that our colleagues are not receptive to open discussion of these topics? Anthropologists seem to have none of our qualms. Melinda Hinkson (2018) asks in a recent article, "can anthropology hold

This article is protected by copyright. All rights reserved. 
together a genuinely refigured relationship to Indigenous communities and local knowledge, and to its own appropriative tendencies, while at the same time championing the role of critical, abstract techniques for analysis and comparison?" If we substitute "linguistics" for "anthropology," this is a question that also resonates with many linguists.

Anthropologists and others in the humanities have been grappling with this very question for some time (Smith 2013). How can we do academic research with Indigenous communities without contributing to the colonization project? Linguists working on endangered languages have not participated much in discussions of decolonization. Suspicions that the other humanities disciplines are overly influenced by poststructuralism, said to cause "pointless navel-gazing," creates a situation in which more empirically oriented linguists miss out on intellectual developments occurring across the humanities. However, a recent book by Stebbins, Eira, and Couzens (2017) discusses decolonization and the revitalization of Indigenous Australian languages. The outcome of a decade-long collaboration between a non-Indigenous university-based linguist (Stebbins), a nonIndigenous community-based linguist (Eira), and an Indigenous artist, linguist, and activist (Couzens), this book has been well received by community-based linguists and Indigenous communities revitalizing their languages.

The idea that linguists who work with Indigenous Australian communities don't see politics is untrue. Of course we learn about the impacts of past and present colonialism when we live and work with Indigenous people in remote areas who have experienced colonial oppression now over many, many generations. It is not possible to look away while the children of the people you work with are denied the right to use their language in school or when they are taken away by child protection and nearly forget their own language. Linguists who do research with Australian Indigenous communities generally build strong research partnerships with these communities and often do much work that is not only practical but also political, supporting languages in the community and advocating for greater government support for Indigenous languages.

Despite these strong partnerships with Indigenous communities where we do our research, many linguists feel that our position at the university and within Australian Indigenous/nonIndigenous relations more broadly is becoming ever more fraught. Our discussions around tensions between the academy and Indigenous communities would be much more productive if they took place in public. In fact, as Roche points out, such discussions are central to moving research on language endangerment forward and bringing the field of language documentation onto firmer

This article is protected by copyright. All rights reserved. 
ethical ground. If linguists at universities strengthened their partnerships with other humanities disciplines, with Indigenous scholars, and with community-based linguists, we could have a much greater impact on language endangerment.

\section{REFERENCES CITED}

Davis, Jenny L. 2018. Talking Indian: Identity and Language Revitalization in the Chickasaw Rehaissance. Tucson: University of Arizona Press.

Hinkson, Melinda. 2018. "Beyond the Hot Take." Cultural Anthropology website, September 26. https://culanth.org/fieldsights/beyond-the-hot-take.

Shotwell, Alexis.2016. Against Purity: Living Ethically in Compromised Times. Minneapolis: University of Minnesota Press.

Singer, Ruth, and Jill Vaughan, eds. 2018. "Indigenous Multilingualisms." Special issue of Language and Communication 62 (B).

Smith, Linda Tuhiwai. 2013. Decolonizing Methodologies: Research and Indigenous Peoples. London: ZeđBooks.

Stebbins, Tonya N., Kris Eira, and Vicki L. Couzens. 2017. Living Languages and New Approaches to Language Revitalisation Research. New York: Routledge.

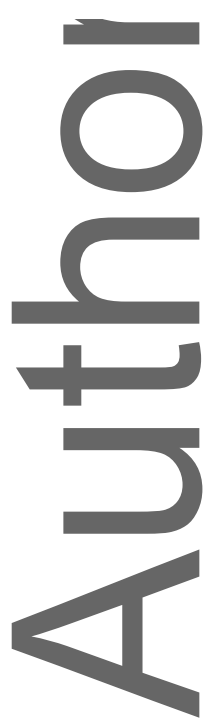

This article is protected by copyright. All rights reserved. 


\section{University Library}

\section{- M M I N E R VA A gateway to Melbourne's research publications}

Minerva Access is the Institutional Repository of The University of Melbourne

Author/s:

Singer, $R$

Title:

Why Don't Linguists Talk about Politics? Moving Forward on Language EndangermentTogether

Date:

2020-03-01

Citation:

Singer, R. (2020). Why Don't Linguists Talk about Politics? Moving Forward on Language Endangerment-Together. AMERICAN ANTHROPOLOGIST, 122 (1), pp.175-177

Persistent Link:

http://hdl.handle.net/11343/276856 